\title{
The Problems of Investment Climate in Uzbekistan
}

\author{
Umar Burkhanov $^{1}$, Mansoor Maitah ${ }^{2} \&$ Kholnazar Amonov ${ }^{3}$ \\ ${ }^{1}$ Tashkent State Universiy of Economics, Uzbekistan \\ ${ }^{2}$ Faculty of Economics and Management, Czech University of Life Sciences Prague, Czech Republic \\ ${ }^{3}$ Central Bohemia University, Czech Republic \\ Correspondence: Mansoor Maitah, Department of Economics, Faculty of Economics and Management, Czech \\ University of Life Sciences Prague, Kamycka 129, Prague 6 16921, Czech Republic. E-mail: maitah@pef.czu.cz
}

Received: January 22, 2015 Accepted: April 24, 2015 Online Published: July 30, 2015

doi:10.5539/res.v7n11p232 URL: http://dx.doi.org/10.5539/res.v7n11p232

\begin{abstract}
The paper aims to give some insights into the investment environment and the analyses of factors influencing. The study is motivated by the high failure rate of foreign investments in Uzbekistan The findings of the study will benefit both local investors who are interested in learning about contemporary methods of investment valuation and foreign investors who are interested in assessing investment opportunities in Uzbekistan. The complexities of evolution of investment opportunities in emerging markets have been studied before. The problems associated with transparency, foreign exchange volatility and liquidity, contagion, governance, political risks (Note 1), and corruption have differing impacts on pricing and valuation across countries and regions. Uzbekistan is a newly-independent Central Asian country, where the same approaches of valuation methods are employed as in Russia, the Ukraine, and other European parts of the former Soviet Union. The provided analysis of investment climate in Uzbekistan suggests that the currency convertibility, lack of transparency and predictability, overregulated financial sector, limiting ownership and restrictions in "strategic" sectors are the greatest obstacles for many potential foreign investors. Also, inadequacies in investment policy and underdevelopment of stock exchange resulted $60 \%$ of all foreign investments went to energy sector. Overall business climate in Uzbekistan can be described as stable, but with a potential for rapid growth in the event of more radical reforms towards market.
\end{abstract}

Keywords: Uzbekistan, investment climate, foreign direct investments, investors

\section{Introduction}

According to PWC study (2013), Uzbekistan has enormous investment potential such as relatively low costs of production factors, significant domestic market, and easy access to CIS markets. However, companies that have invested in Uzbekistan have had trouble assessing the country-specific risks (Tsamenyi \& Tauringana, 2004) and lack of reliable statistics on economy makes the pricing process more difficult (Peimani, 2009). According to the Advanced Financial Solution's (AFS) research, the highest GDP growth rates in top ten fastest growing countries in 2011 were as follows: Qatar 15.8\%, Ghana 12\%, Mongolia 12\%, Eritrea 9.3\%, Ethiopia 9\%, China 8.9\%, and India $8.6 \%$. Uzbekistan was in the top ten with the annual growth rate of $8.3 \%$.

As can be seen from Figure 1 below, except fast economic growth the other economic factors that make Uzbekistan attractive to foreign investors include: undervalued assets, investment incentives, adequate infrastructure, low cost of energy/utilities, large internal market of about 30 million people, and free trade zone with 11 CIS member-states forming a regional market of over 277 million people. Moreover, there are many project opportunities in the current investment program in oil and gas, coal, mining, electric power generation, chemical, food processing, and tourism as reported by US Department of State. The role of small business and private entrepreneurship in the country's GDP and economy is increasing. According to State Statistics Committee report, this sector generated $54.6 \%$ of the GDP and created $75.7 \%$ of employments to the population in 2012 . 

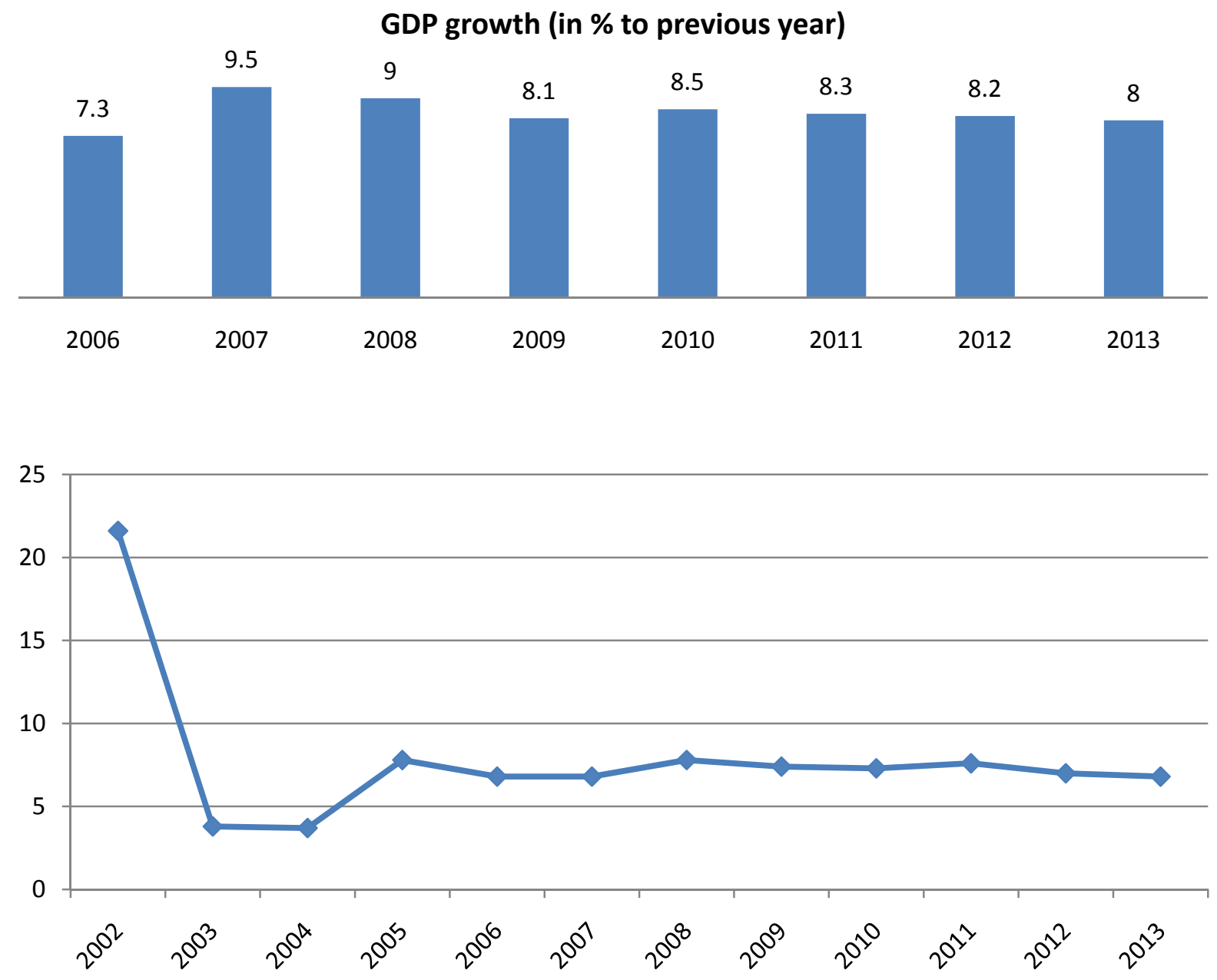

Figure 1. Main trends of socio-economic development

Sources: Ministry for Foreign Economic Relations, Investments and Trade of the Republic of Uzbekistan. 2014.

The government of Uzbekistan declares that attracting foreign direct investment is core priority and there were more than 50 legislative documents issued to accelerate and coordinate investment processes. They include the Law on Foreign Investments, the Law on Guarantees and Measures on Protection of Foreign Investments, the Law on Guarantees of the Freedoms of Entrepreneurial Activity, the Production Sharing Agreements Law, the Law on Investment Activities, the Law on Protection of Private Property and a number of relevant government decrees. The legislation of Uzbekistan provides a wide range of guarantees for foreign investors, including: protection against discrimination, protection from harm caused by retroactive implementation of legislation, protection from interference by the state in the economic activity of foreign investors, and protection from any changes in legislation that worsens foreign investment conditions and etc., reveals by PWC (2013) study. Whilst there have been improvements in the recent years in the economic situation in Uzbekistan, the economy of the country continues to display some characteristics of an emerging market. These characteristics include, but are not limited to, the existence of a currency that is not freely convertible outside of the Republic of Uzbekistan and a low level of liquidity in debt and equity markets. Although the global financial crisis has hardly affected the domestic financial sector directly, it has slowed exports, remittances, and investment due to slower economic growth in Russia, Kazakhstan and certain other Uzbekistan's large trading partners (PWC, 2013).

According to IMF regional forecast (as reported in gazeta.uz, 2014) the growth in Central Asia \& Caucasus will slow down to $1 \%$ of GDP as a result of Russian Economic turmoil (caused by Western sanctions and dropping oil price), which influence through foreign trade, investments and remittances. Long lasting of slow growth rates in EU and China will negatively affect also, according to the report. As oil prices hits four year low the risks of 
forecasting is increasing and reduced demand from Russia gives more pressure on Trade balance.

As can be seen Table 1, despite the fact that Uzbekistan made some improvements in World Bank's Doing Business Index, the countries ranking in main International Indexes is still needs to be improved (Investment Climate Statement, Bureau of Economic and Business Affairs, Heritage Economic Freedom Index). The counties indicators such as getting electricity, protecting investor rights and paying taxes were worsened in 2014 comparing to previous year. According to Investment climate statement of US Department of State (2013) Uzbekistan investment climate description is contradictory where government official statistical data on investment inflows is not always reliable. The currency convertibility, lack of transparency and predictability, overregulated financial sector, limiting ownership and restrictions in "strategic" (airlines, railway, power generation, media, banking, insurance and tourism) sectors deemed to be the greatest obstacles for many potential foreign investors. The overall business climate may be described as stable, but with a potential for rapid growth in the event of more radical reforms towards market economy and reduced state regulation of the Economy.

Table 1. The changes of Uzbekistan's indicators in World Bank's-Doing Business Index

\begin{tabular}{clcccc}
\hline No & Indicators & DB-2013 & DB-2014 & \multicolumn{2}{c}{ changes } \\
\hline & Ranking & 156 & 146 & $\boldsymbol{\uparrow}$ & 10 \\
1. & Starting a business & 87 & 21 & $\boldsymbol{\uparrow}$ & 66 \\
2. & Dealing with construction permits & 160 & 159 & $\boldsymbol{\uparrow}$ & 1 \\
3. & Getting electricity & 169 & 173 & $\boldsymbol{\downarrow}$ & -4 \\
4. & Registering property & 142 & 136 & $\boldsymbol{\uparrow}$ & 6 \\
5. & Getting credit & 154 & 130 & $\boldsymbol{\uparrow}$ & 24 \\
6. & Protecting investors & 137 & 138 & $\boldsymbol{\Downarrow}$ & -1 \\
7. & Paying taxes & 165 & 168 & $\boldsymbol{\downarrow}$ & -3 \\
8. & Trading across borders & 189 & 189 & $\leftarrow \rightarrow$ & 0 \\
9. & Enforcing contracts & 42 & 40 & $\boldsymbol{\uparrow}$ & 2 \\
10. & Closing a business & 71 & 63 & $\boldsymbol{\uparrow}$ & 8 \\
\hline
\end{tabular}

Source: Authors' calculations based on the World Bank Doing Business Index Report, 2014.

The survey carried out by Center of Economic Research (CER, 2011) among 700 national companies showed the following barriers hinder the higher business results: bank loans receiving conditions (the conditions of the collateral), the credit process and the charging rates for services; the non-cash purchase of raw materials and quality of natural gas supply. As a result, as can be seen in Figure 2, 60\% of all foreign investments went to energy sector. 


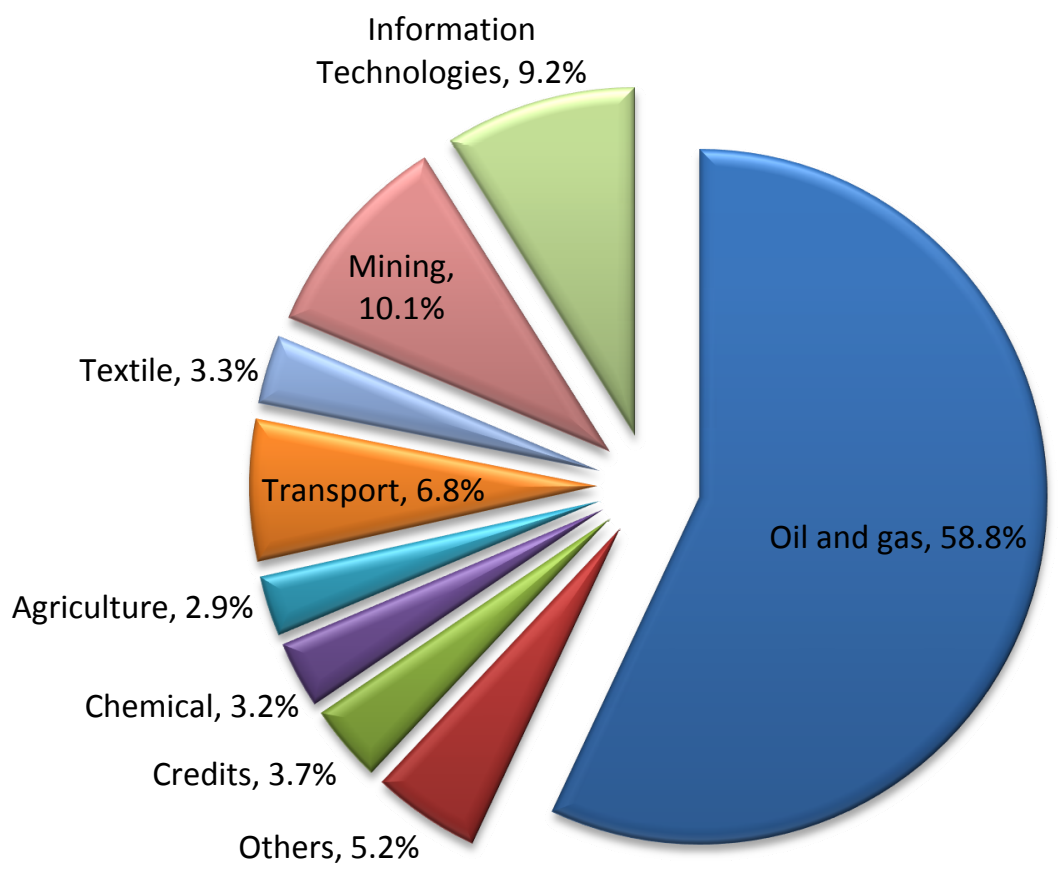

Figure 2. Foreign direct investments in Uzbekistan, 2012

Source: Ministry for Foreign Economic Relations, Investments and Trade of the Republic of Uzbekistan. 2014.

\section{Method}

The study is conducted using data from two main sources: a questionnaire and document analysis. A template of the questionnaire of 50 exporter companies (including 7 public, 24 private, 7 state owned, 5 joint-venture and 7 other ownership) can be found in Appendix A. Questionnaires were mailed to company directors and table 2 shows the results. Document analysis includes analysis of statistics of official government bodies and international organizations. Moreover, the international and domestic publishing were used for imperative analysis of Uzbek economy.

Table 2. Responses

\begin{tabular}{lc}
\hline Questionnaires sent out & 50 \\
Useable questionnaires received & 36 \\
Percentage response rate & $72 \%$ \\
\hline
\end{tabular}

\section{The problem of using contemporary valuation approaches}

The problem of valuation of investments in Uzbekistan is deepening with existing structural and institutional problems in economy. Methodological issues making valuation process in Uzbekistan challenging even with the use of most popular ad-hoc methods (Note 2):

- No government bonds issued as Uzbek government declares the absence of deficits in State budget from 2004 (Note 3);

- Lack of well-diversified stock exchange to calculate company beta as more than $65 \%$ of Tashkent Stock exchange (the main stock market in country) consists of the financial sector (see Figure 3);

- Absence of sovereign ratings by main Credit Rating agencies (Note 4). However, the only country rating given by The Trading Economics is 15 out of 100 which is equal to CCC or Caa2. 


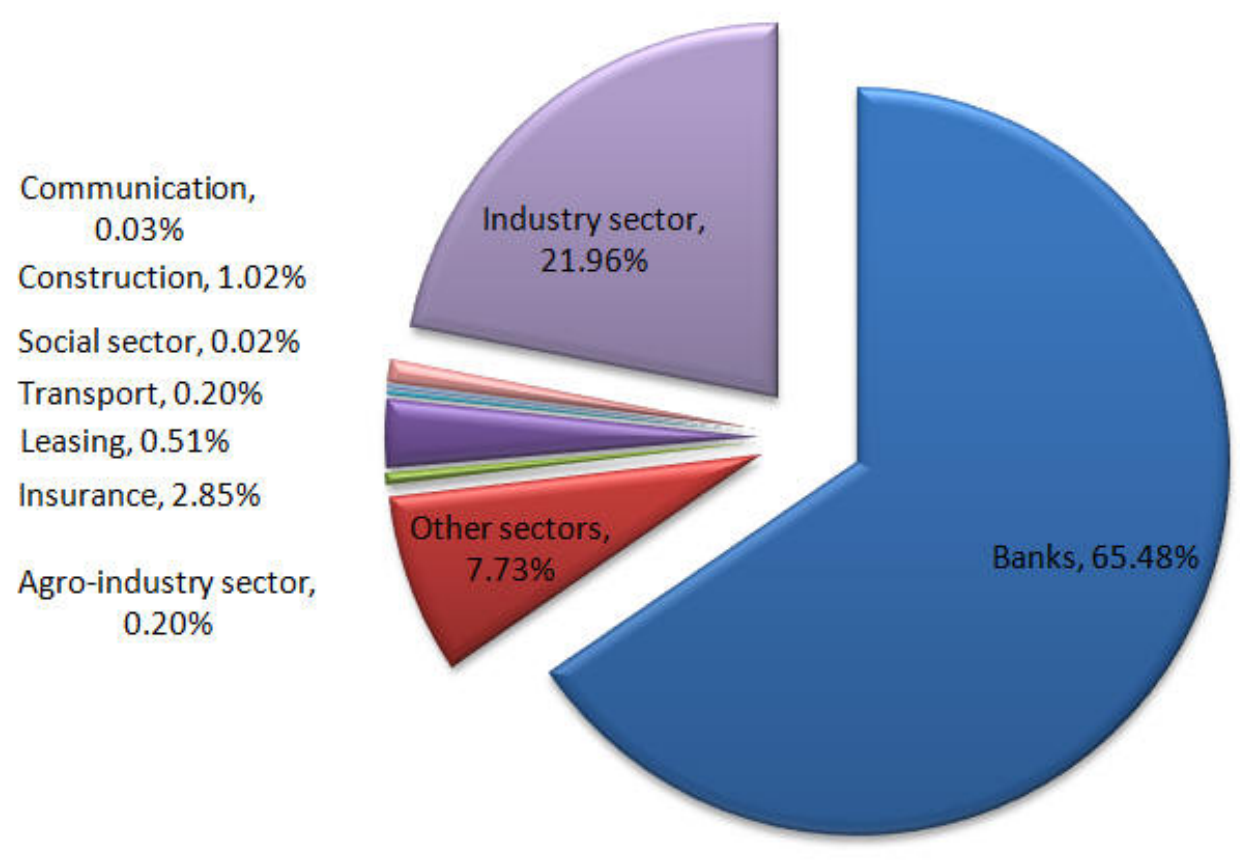

Figure 3. The structure of Tashkent stock exchange by sectors

Source: Tashkent Stock Exchange Reports (2012)

The insufficiencies further complicating the process of valuation are difficulties incorporation high currency risks into valuation due to multiple exchange rate (Tsamenyi \& Tauringana, 2004) and complexities of future cash flow forecasting due to lack of financial experts (institutions) in the market. As the financial sector shows signs of segmentation (UN, 2003), and despite the recent improvements in business freedom index (Index of Economic Freedom, 2014), more reforms needed towards to market liberalization.

Estimating the cost of capital for a firm is other major hurdle for investors in deriving discounted cash flow (DCF) methods. As a result, local investors using standard (country) discount rate of $15 \%$ as in 2014 (Central Bank's interest rate $10 \%$ multiplied by 1.5 , according to chapter 36 of National standards of Asset pricing) which not takes into account project specific risks. Only $30 \%$ of US counterparts prefer using country specific risks according to Graham and Harvey (2001, JFE).

The companies surveyed were exporters whom the decision-makers assumed to be familiar with contemporary methods of investment valuation.

The analysis suggests that majority of firms that responded to the survey (19 out of 36 or 53\%) employ less than 50 employees which shows they belong to small-sized firms. Only $36 \%$ of respondents employ more than 200 employees. The most popular among respondents was Payback period with more than $37 \%$, NPV \& IRR were in the second place with $17 \%$ managers prefer them respectively.

This trend shows consistency with the Graham and Harvey (2001) for US small firms, as small-sized firms more consider liquidity as they have limited access to finance. This finding is consistent with Tsamenyi \& Tauringana (2004) who argued that one reason managers not prefer to use DCF methods is difficulties of estimating the real discount rate and impossibility of predicting profits for a period of more than one year. Nearly $53 \%$ of the firms surveyed indicated the proportion of debt in the capital structure is not more $10 \% .19 \%$ of companies showed have not more than $25 \%$ debt capital. Only about $17 \%$ respondents answered they have more than $50 \%$ debt capital. The results of survey is consistent with the findings of CER (2011), which according to it is results $60 \%$ of respondents have less than $10 \%$ and only $2 \%$ have more than $50 \%$ debt capital. This can be explained with the absence of tax shield and underdevelopment of stock markets, difficulties obtaining bank loans.

When asked about the price of debt, surprisingly the most of surveyed companies (39\%) answered the price of borrowing is the lower than 5\% annually. At $25 \%$ companies cost of debt was between 5 to $10 \%$ and only $14 \%$ respondents answered the price of their debt capital costs more than $25 \%$. The only reasonable explanation of this cheap debt capital could be the existance of state support of exporters by prefered credit system which 
non-exporters have no access. Differently from the answers to previous question, the trend for the equity price among the respondents was multi-directed. The only $11 \%$ companies answered that their equity price was below $5 \%$ and $14 \%$ more companies' equity price was between 5 to $10 \%$. The $22 \%$ of respondents paid the most expensive price (more than 50\%) and the same answer obtained for the price range of $10-15 \%$. The multi-direction can be explained that most of respondents belong to private firms (in many cases the managers are the owners) at which estimation of equity price was not properly calculated. Lack of studies on the capital price in Uzbekistan and underdevelopment of stock markets makes impossible to cross comparing the results of this survey section. As other background information the respondents were also asked to rank the factors that influence to their financial condition. This question was necessary to examine whether businesses perception of degree of risk in Uzbekistan when they making investments. About $42 \%$ of respondents noted that their business is sensitive to changes in taxes, while $22 \%$ answered changes in customs are the most influential to their business. The monetary tools such as changes in currency rate and interest rates assessed as risk factor by $19 \%$ and $8 \%$ respondents respectively

\section{Conclusion}

This article provides empirical evidence on investment climate and corporate valuation practices in Uzbekistan. The study is motivated by the controversial evidence of investment climate in Uzbekistan and lack of universal methodologies of investment valuation in emerging markets general. The provided analysis of investment climate in Uzbekistan suggests that the currency convertibility, lack of transparency and predictability, overregulated financial sector, limiting ownership and restrictions in "strategic" sectors are the greatest obstacles for many potential foreign investors. Also, inadequacies in investment policy and underdevelopment of stock exchange resulted $60 \%$ of all foreign investments went to energy sector. Overall business climate in Uzbekistan can be described as stable, but with a potential for rapid growth in the event of more radical reforms towards market.

The absence a sovereign credit rating, lack of well diversified stock exchange markets, difficulties of incorporation of high currency risks into valuation due to multiple exchange rates and complexities of future cash flow forecasting are the main problems making valuation difficult in Uzbekistan. The survey revealed that most companies use Payback Period appraising technique for capital budgeting and $60 \%$ of respondents have less than $10 \%$ of debt in their capital structure. These findings are consistent with previous surveys (CER, 2011, Tsamenyi \& Tauringana, 2004), except the results for cost of capital. The low cost borrowing for the most of surveyed companies explaned by the existance of state support of exporters by prefered credit system. The multi-direction of equity price can be explained lack of estimation skills of private firm managers. In terms of risk, changes in taxation, in customs, currency rate have been rated as the most risk factors for surveyed companies respectively.

In sum, while this research attempts to assess investment environment and to provide empirical evidence of valuation practices of companies in Uzbekistan, the simple is too small for generalization. However, this research will provide some insides of investment environment of Uzbekistan and reveals existing problems in valuation practices for future research.

\section{References}

Abrams, S. (2002). A Practical Approach to the International Valuation and Capital Allocation Puzzle. Salomon Smith Barney.

Bruner, R. et al. (2002). Introduction to "Valuation in Emerging Markets". Emerging Markets Review, 3. http://dx.doi.org/10.1016/S1566-0141(02)00039-0

Colin, J. (1998). State Keeps a Tight Rein: Market Reform in Uzbekistan. The Banker, 14(8), 47-50.

Estrada, J. (2007). Discount rates in emerging markets: Four models and an application. Journal of Applied Corporate Finance, 19, 72-78. http://dx.doi.org/10.1111/j.1745-6622.2007.00137.x

Estrada, J. (2002). Systematic risk in emerging markets: The D-CAPM. Emerging Markets Review, 3, 365-379. http://dx.doi.org/10.1016/S1566-0141(02)00042-0

James, M., \& Koller, T. (2000). Valuation in emerging markets. Corporate Finance, 4, 78-85.

Koller, T., \& Murrin, J. (2000). Valuation: Measuring and Managing the Value of Companies (3rd ed.). New York: John Wiley \& Sons.

Luehrman, T. (2009). Business valuation and the cost of capital. Boston: Harvard business school publishing.

Luehrman, T. (1997). General manager's guide to valuation. Harvard Business Review. 
Peimani, H. (2009). Conflict and Security in Central Asia and Caucasus. Calif: Santa Barbara.

PRICEWATERHOUSECOOPERS. (2013). Guide to doing business and investing in Uzbekistan. Retrieved from http://www.pwc.com/uz

Tsamenyi, M., \& Tauringana, V. (2004). Capital budgeting and budgeting practices of foreign operations in Uzbekistan: An exploratory study. International Journal of Strategic Cost Management, 20-36.

UNs Economic and Social Commission for Asia and Pacific. (2003). Managing globalization in selected countries with economies in transition. New York: United Nations.

Yescombe, E. (2007). Public-Private partnerships. Principles of Policy and Finance. UK: Published by Elsevier ltd.

\section{Notes}

Note 1. A 2001 PWCs study concluded that an opaque policy-making environment is equivalent to at least a $33 \%$ increase in taxation. According to the World Bank (2004) study $15 \%$ to $30 \%$ of the contracts covering $\$ 371$ bln. of private infrastructure investment were subject to government-initiated renegotiations or disputes.

Note 2. Such as the Lessard approach, the Goldman Sachs approach, the SalomonSmithBarney approach, the Godfrey-Espinosa approach (Estrada, 2007).

Note 3. Since EM government bonds cannot be considered riskless investments it is suggested adding the inflation rate differential between the local economy and a developed nation and using that as a spread on top of that same developed nation's long-term bond yield (CFA Institute, 2011).

There are several methods: the current market rate for government bonds (Ireland, the Netherlands and the US); or a fixed rate based on the historical average for government bonds; or the "social time preference rate", the rate which private investors expect to receive for foregoing present consumption in favor of future consumption assuming is a risk-free transaction (Yescombe, 2007).

Note 4. Uzbekistan intends to obtain a sovereign credit rating by 2015 , the Uzbek government reported in a state economic development program, according to Trend News Agency (2014).

\section{Appendix A}

Please select the ownership that your company belongs to:

1. Public

2. Private, Ltd

3. State

4. Joint-Venture

5. Other

What is the size of your company in terms of number of employees?
1. $200 \leq$
2. $100 \leq 200$
3. $50 \leq 100$
4. $25 \leq 50$
5. $\leq 25$

What is the proportion of debt (bank loans, bonds and other) in the capital of your company?
1. $75 \% \leq 100 \%$
2. $50 \% \leq 75 \%$
3. $25 \% \leq 50 \%$
4. $10 \% \leq 25 \%$
5. $\leq 10 \%$ 


\section{What is the method you use to make investment decisions?}

1. Payback period \& Dicounted payback period;

2. Average Rate of Return - ARR or ROI;

3. Net Present Value;

4. Internal Rate of Return;

5. Profitability Index;

6. Other methods (please specify)

What is the biggest factor influencing financial condition of your company?

1. Change in taxes;

2. Change in customs;

3. Currency rate (official \& Black market);

4. Change in interest rate;

5. Others (please specify)

What is the equity and debt price of your company?

\begin{tabular}{|l|l|}
\hline Equity price & Debt price \\
\hline 1. $50 \% \leq$ & 1. $50 \% \leq$ \\
2. $25 \% \leq 50 \%$ & 2. $25 \% \leq 50 \%$ \\
3. $15 \% \leq 25 \%$ & 3. $15 \% \leq 25 \%$ \\
4. $10 \% \leq 15 \%$ & 4. $10 \% \leq 15 \%$ \\
5. $5 \% \leq 10 \%$ & $5.5 \% \leq 10 \%$ \\
6. $\leq 5 \%$ & 6. $\leq 5 \%$ \\
& \\
\hline
\end{tabular}

\section{Copyrights}

Copyright for this article is retained by the author(s), with first publication rights granted to the journal.

This is an open-access article distributed under the terms and conditions of the Creative Commons Attribution license (http://creativecommons.org/licenses/by/3.0/). 